\title{
Interaction efficiency of Trichoderma spp. and some plant extracts against ear-cockle disease
}

\author{
Azher Hameed Faraj Al-Taie* (D), Noor Kadhum Al-Zubaidi \\ Plant Protection Department, College of Agriculture, Wasit University, Kut, Iraq.
}

\section{ARTICLE INFO \\ Article history: \\ Received on: May 26, 2021 \\ Accepted on: July 29, 2021 \\ Available online: February 15, 2022}

\section{Key words:}

Anguina tritici, bioassay, licorice extract, seaweed extract, Trichoderma

\begin{abstract}
Ear-cockle disease is one of the important aerial diseases of wheat. It is caused by wheat seed gall nematode Anguina tritici. This study aimed to evaluate the interaction effect between Trichoderma spp. as bioagents and some plant extracts. The latter are used as alternative substances to control the seed gall nematode in both laboratory and field conditions. The bioassay of juveniles in the second stage $\left(\mathrm{J}_{2}\right)$ of $A$. tritici was' conducted using the biopesticide Biocont-T-WP (Trichoderma harzianum), isolate of Trichoderma hamatum T-113, and nematic and seaweed extract for their effect on the viability of $A$. tritici $\mathrm{J}_{2}$. nematicide Rugby 100 has been used as a positive control." The lab-bioassay was achieved on the daily accumulated $\mathrm{J}_{2}$ mortality percentage during $[1,3,5,7,9$, and 11 days of incubation, while the field-bioassay was evaluated for" wheat growth, yield, and infection attributes.'The lab-bioassay showed that Biocont-T has a higher mortality effect followed by the nematic extract with averages of $40.56 \%$ and $12.52 \%$, respectively. The accumulative $\mathrm{J}_{2}$ mortality percentage increased gradually and reached a maximum on the 11 th day of incubation. In the field-bioassay, mixing wheat [seed Ibaa-99 with Biocont-T decreased infection percentage $77.7 \%$ and the number of galls spike ${ }^{-1}$ to 1.63 compared to the control 5.66 galls spike ${ }^{-1}$.
\end{abstract}

\section{INTRODUCTION}

Wheat (Triticum aestivum) is a major crop in Iraq. Wheat lyield faced different types of pests that may affect it negatively. Wheat is cultivated all over Iraq with an approximate area that exceeds 1.7 million ha. The Iraqi people consume, on average, nearly 7 million $t$ of wheat per year [1].

Ear-cockle disease is one of the aerial diseases affecting wheat, caused by wheat seed gall nematode Anguina tritici (Steinbuch), which is considered a major pest in Iraq in addition to all wheat production areas in the world. The juveniles $\left(\mathrm{J}_{2}\right)$ emerge from the wheat galls in the soil, lattack plants, and move into the germinated seedlings. Next, $\mathrm{J}_{2}$ will move up to the spikes hurting new grains, turning the seed into seed galls, then causing major loss in the grain yield quality and quantity [2]. During the harvesting process,

*Corresponding Author

Azher Hameed Faraj Al-Taie, Plant Protection Department, College of Agriculture, Wasit University, Kut, Iraq.E-mail: aaltaie@ uowasit.edu.iq galls might fall into the soil and be a source of new infection that would be generated in the following season [3].

In Iraq, the first record of $A$. tritici was reported by [4], which recorded it as plant parasite nematode [5]. Al-Beldawi et al. [6] revealed that most wheat cultivars in Iraq are susceptible to infection with ear-cockle disease except var. Mexipak which showed resistance to this nematode. The infection rate is affected by several factors such as the number of inoculums $\left(1 \mathrm{gall} \mathrm{cm}^{-2}\right)$ and time and method of infection [7]. Stephan et al. [8] revealed that the infection in wheat fields recorded in most of Iraq's provinces ranged between $22.9 \%$ and $75 \%$, while Ami et al. [9] also reported that the infection rate in wheat in northern Iraq reached $50 \%$.

The ear-cockle disease reduces not only human consumption but also the marketing price of wheat. Protein and gluten contents of the flour of infected wheat with seed galls will diminish as well [10].

Chemical control is an effective method to control the ear-cockle disease. A wide range of nematicides is used to control this disease. However, nematicides' high toxicity, high hazard, and long persistence in the environment besides appearing resistant 
strains for this kind of pesticides make it a real challenge to control this pest [11]. Thus, many researchers have attempted to test new compounds to control this pest. These attempts include the possibility of using some insecticide and fungicide (either chemical or organic) in addition to plant extracts to control this pest and overcome appearing resistant strains besides long-term residue $[12,13]$.

Based on few studies conducted in Iraq to reduce the effect of ear-cockle disease of A. tritici, [14] used chitin synthesis inhibitor cyromazine (Trigard) in addition to [15] that used fungicides Divident 030FS, Vitavax 200Wp, Dithane S-60D, and herbicide Granstar 75D.F. Due to the massive effect of this disease on wheat, causing a reduction in the yield, and in order to manage such challenge, the study aimed to evaluate the efficiency of some bioagent of Trichoderma spp. in addition to some plant extracts for use as alternative substances to control seed gall nematode $A$. tritici under laboratory and field conditions.

\section{MATERIALS AND METHODS}

Galls of A. tritici were collected from infested samples of wheat (Ibaa-99) obtained from the Department of Seed Test and Certification and Center of Receiving Wheat Grain in Wasit Province, Iraq. Anguina tritici $\mathrm{J}_{2}$ suspension was prepared by immersing galls in distilled water for 2 hours $\mathrm{J}_{2}$ suspension was transferred to a beaker and the nematode population was counted under a stereomicroscope using slid count nematodes. $1 \mathrm{ml}$ of $\mathrm{J}_{2}$ suspension was prepared to obtain $50 \pm 5 \mathrm{~J}_{2} \mathrm{ml}^{-1}$.

The study was conducted in the laboratory and field of the College of Agriculture, Wasit University, during the 2017-2018 agricultural season. The bioassay was conducted in the following ways.

\subsection{Lab-Bioassay}

First, in vitro as lab-bioassay, by preparing $1 \mathrm{ml}$ of the $\mathrm{J}_{2}$ suspension in a $50 \mathrm{~mm}$ Petri dish and $1 \mathrm{ml}$ of substances, the five treatments (Table 1) were added to a Petri dish separately with the recommended concentration in triplicate. The control treatment contained $\mathrm{J}_{2}$ with distilled water only. All Petri dishes were covered with plastic bags and incubated at $26^{\circ} \mathrm{C} \pm 2^{\circ} \mathrm{C}$ for 1 , $3,5,7,9$, and 11 days, respectively. This experiment was repeated to confirm the results.

The effects of treatment were evaluated by the $\mathrm{J}_{2}$ moving test during the incubation period. A sample of dead $J_{2}$ was differentiated based on the method in Ref. [16]: (1) straightness of juveniles and color alternation to brown and (2) making sure that juveniles are not moving when transferred to the water for $2-3$ hours. The mortality percentage $\mathrm{J}_{2}$ was calculated during the period of incubation and corrected according to the following equation [17]

Corrected mortality (\%)

$$
=\frac{\text { number of living juveniles in the treatment }}{\text { number of living juveniles in the control }} \times 100-100
$$

\subsection{Field-Bioassay}

Field-bioassay was conducted by preparing plastic pots $(25 \times 25$ $\times 25 \mathrm{~cm}$ ) filled with soil infestation by 10 galls/pot and sowing five seeds of wheat (Ibaa-99) per pot after treatment with the five treatments separately (Table 1) with three replicates. The pots were also sprayed with all treatments at leaf age of two of planting. The control treatments were sprayed with distilled water only. Pots were placed under field conditions and irrigated when needed.

The efficiency of treatments was evaluated, after harvesting and collecting wheat's spike, according to wheat growth, yield, and infection attributes: germination percentage, number of branches/ plants, plant length $(\mathrm{cm})$, spike length $(\mathrm{cm})$, spike weight $(\mathrm{g})$, number of seed spike ${ }^{-1}$, and number of galls spike ${ }^{-1}$. The infection percentages were calculated according to the following equation:

Infection percentage $(\%)$

$$
=\frac{\text { number of infected plants in pot }}{\text { total number of plants in pots }} \times 100
$$

\subsection{Statistical Analysis}

The study was conducted in a factorial complete randomized design. The data were analyzed using Genstat statistical software and Microsoft Excel. Means were compared using Least significant differences (L.S.D) at the probability level of $p \leq 0.01$ for laboratory experiment and $p \leq 0.05$ for pot experiment. The Regression analysis is used to determine the relationship between treatments and accumulated mortality percentage during incubation periods [18].

\section{RESULTS AND DISCUSSION}

The results of the lab-bioassay indicate that all treatments caused $\mathrm{J}_{2}$ mortality of $A$. tritici particularity Biocont-T with $40.56 \%$ as compared to other treatments (Table 2). The biopesticide Biocont-T had better efficiency than isolate T-113 in average accumulated $\mathrm{J}_{2}$ mortality percentage of $\% 40.56-9.01 \%$, respectively. The results of the plant extract also showed that Nematic was more efficient on accumulated $\mathrm{J}_{2}$ mortality than licorice extract $(12.52 \%$ and $8.22 \%$, respectively) compared to control treatment $(0.33 \%)$.

Table 1: Treatments of the study.

\begin{tabular}{lllc} 
Treatment & Formulation & Compound & Concentration \\
Biocont-T (biopesticide) & WP & Trichoderma harzianum & $19 \times 10^{7}$ spores ml $^{-1}$ \\
T-113 & Spore suspension & Trichoderma hamatum & $19 \times 10^{7}$ spores ml $^{-1}$ \\
Bio Atlantis Nematic & EC & Seaweed extract & $2.5 \mathrm{ml} \mathrm{l}^{-1}$ \\
Licorice extract & WP & Licorice root extract & $1 \mathrm{~g} \mathrm{l}^{-1}$ \\
Rugby 100 (negative control) & ME & Cadusafos & $1 \mathrm{ml} \mathrm{l}^{-1}$ \\
\hline
\end{tabular}


Table 2: Effect of Trichoderma spp. and plant extracts on $\mathrm{J}_{2}$ mortality percentage of A. tritici during periods of incubation.

\begin{tabular}{|c|c|c|c|c|c|c|c|}
\hline \multirow{2}{*}{ Incubation periods (day) Treatments } & \multicolumn{6}{|c|}{ Average accumulated of $\mathrm{J}_{2}$ mortality (\%) } & \multirow[b]{2}{*}{ Mean } \\
\hline & 1 & 3 & 5 & 7 & 9 & 11 & \\
\hline Biocont-T & 0 & 10.1 & 19.1 & 43.5 & 77.6 & 92.8 & 40.5 \\
\hline $\mathrm{T}-113$ & 0 & 2.1 & 8.1 & 11.0 & 15.0 & 17.7 & 9.0 \\
\hline Nematic & 4 & 4.7 & 6.1 & 15.5 & 19.3 & 25.3 & 12.5 \\
\hline Licorice extract & 5.6 & 6.6 & 8.2 & 8.5 & 8.8 & 9.0 & 8.2 \\
\hline Rugby & 32.6 & 39.3 & 43.5 & 54.0 & 61.7 & 70.0 & 50.2 \\
\hline Control & 0 & 0 & 0 & 0 & 1 & 1 & 0.3 \\
\hline Mean & 8.2 & 12.0 & 14.1 & 24.4 & 33.4 & 39.0 & \\
\hline L.S.D. $1 \%$ treatment & & & & & & & 3.99 \\
\hline L.S.D. $1 \%$ incubation periods & & & & & & & 3.99 \\
\hline L.S.D. $1 \%$ interaction & & & & & & & 9.79 \\
\hline
\end{tabular}

The $\mathrm{J}_{2}$ mortality percentage of $A$. tritici in all treatments during the incubation periods' 1 st to 11 th days has shown a significant effect (Table 2). The means of the accumulated $\mathrm{J}_{2}$ mortality percentage demonstrated that gradual increase was highest on the 11th day with $39.01 \%$. The interaction between treatments and incubation periods revealed a significant effect, while Biocont-T was more toxic to $\mathrm{J}_{2}$ and reached maximum mortality of $92.8 \%$ on the 11 th day of incubation compared to other treatments, especially nematicide Rugby with $88.05 \%$.

Regression analysis results showed a positive relation between all treatments and $\mathrm{J}_{2}$ mortality during incubation periods. $\mathrm{Y}$ demonstrated that incubation periods at $26^{\circ} \mathrm{C}+2{ }^{\circ} \mathrm{C}$ will increase the percentage of $\mathrm{J}_{2}$ mortality, while linear relation for treatments (Fig. 1) referred to a significant relation between the accumulated $\mathrm{J}_{2}$ mortality and incubation period. This was shown by the positive value of factor $R^{2}$ which reached the highest value in treatments T-113 and Biocont-T with 0.987 and 0.954, respectively, and without any significant differences from treatment with nematic with 0.926 , in addition to licorice extract.

The results of the field-bioassay in the pots revealed that treatments had a significant effect on the growth and yield of wheat plants that were inoculated with galls (Table 3 ). It was found that the Biocont- $\mathrm{T}$ showed a significant effect on the $\mathrm{J}_{2}$ mortality reflex on the growth of wheat attributes such as germination percentage, number of plant branches, plant length, spike length, and seed weight and number of seeds in each spike of $60.1 \%, 2.3$ branch plant $^{-1}, 66.8 \mathrm{~cm}, 8.3 \mathrm{~cm}, 0.73 \mathrm{~g}$, and $36.5 \mathrm{seed} \mathrm{spike}^{-1}$, respectively. Meanwhile, there was limited improvement in germination percentage as a result of using Trichoderma in both treatments with Biocont-T and isolate T-113 with $60.1 \%$ and $60.5 \%$, respectively.

The results of treatment effect on wheat infection with $A$. tritici in plastic pots (Table 4) revealed that it has a significant decrease of infection percentage of wheat plant with $\mathrm{J}_{2}$ compared to the control treatment. Biocont-T has the highest effect by decreasing the infection percentage $77.78 \%$ and then T-113 with $80.55 \%$. The other treatments have variable effects compared to the control which infected $100 \%$.

The infection percentage results were reflected on average galls per spike. This has shown that all plants whose seeds were treated with Biocont-T contain the lowest number of galls in their spikes of 1.36 (Table 4). Nematic was also shown to be effective with 1.93 galls per spike. The other treatments had variable effects compared to the control treatments which were 5.66 galls per spike.

Many researchers pointed out that Trichoderma is used to inhibit the growth of plant-parasitic nematodes. The secondary metabolism of Trichoderma includes secretion of chitinase, which is an effective component against many pathogenic microorganisms; furthermore, chitin is one of the cell wall components of nematode eggs. ElHasan et al. [19] reported that Trichoderma species also produced some chemicals, harzianic acid, alamethicins, tricholin, peptaibols, antibiotics, and enzymes, which may oppose nematode feeding.

The biopesticide Biocont-T has been distinguished by an accumulated effect on $\mathrm{J}_{2}$ of $A$. tritici. It was also pointed out by Pandey et al. [20] that Trichoderma provide essential nutrients to plants in addition to their nematode-inhibiting ability and possessing a promising potential of nematode antagonism as well. They release some toxic substances/metabolites against a number of pathogenic fungi and nematodes [21,22].

Ozberk et al. [23] reported that grain yield losses due to A. tritici were reported to be up to $32 \%$. Seed gall also reduced the number of grains spike ${ }^{-1}$, grain weight spike ${ }^{-1}$, test weight $\left(\mathrm{kg} \mathrm{hour}^{-1}\right)$, and 1,000-kernel weight ( $\mathrm{g}$ ) but had no effect on sodium dodecyl sulfate (SDS) protein content (\%). Mohamedova et al. [24] reported that there was significant decrease in yield between verities of wheat caused by nematode $A$. tritici.

Some other studies showed that certain plant parts and extracts possess nematocidal properties; this may be due to the contents of these extracts such as saccharides, proteins, growth regulators, and nutrients. Musa et al. [25] reported that licorice extract contains saccharides, protein, and nutrients $(\mathrm{P}, \mathrm{K}, \mathrm{Cu}, \mathrm{Mg}, \mathrm{Mn}, \mathrm{Fe}$, and $\mathrm{Zn).} \mathrm{Al-Jawary} \mathrm{[26]} \mathrm{also} \mathrm{reported} \mathrm{that} \mathrm{licorice} \mathrm{extract} \mathrm{is} \mathrm{similar} \mathrm{to}$ gibberellin Gibberellic acid $3\left(\mathrm{GA}_{3}\right)$ because it contains mevalonic acid, the bioprimer for GA3, which is responsible for cell division and elongation.

Application of plant parts or extracts to nematode-infested soil can affect nematodes directly and stimulates soil microbes that may 

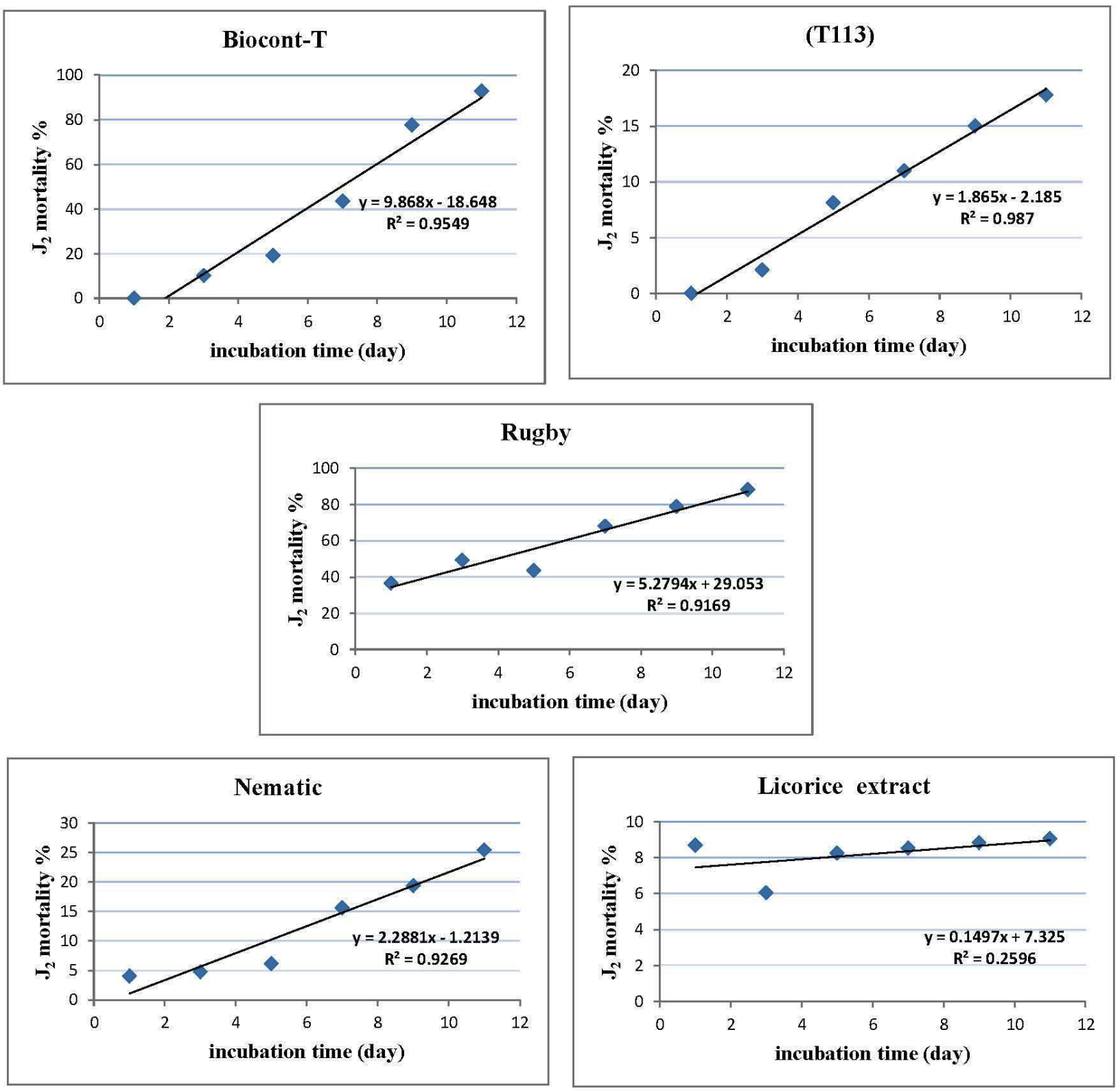

Figure 1: Linear relation between treatments and $\mathrm{J}_{2}$ mortality of $A$. tritici during incubation.

Table 3: Effect of treatments on wheat inoculated with galls of A. tritici.

\begin{tabular}{lcccccc} 
Attributes Treatment & Germination \% & $\begin{array}{c}\text { No. of branches } \\
\text { plant }^{-1}\end{array}$ & $\begin{array}{c}\text { Plant } \\
\text { length }(\mathbf{c m})\end{array}$ & $\begin{array}{c}\text { Spike } \\
\text { length }(\mathbf{c m})\end{array}$ & $\begin{array}{c}\text { Spike } \\
\text { weight (g) }\end{array}$ & $\begin{array}{c}\text { No. of seeds } \\
\text { spike }^{-1}\end{array}$ \\
Biocont-T & 60.1 & 3.2 & 66.8 & 8.3 & 0.73 & 36.5 \\
T-113 & 60.5 & 3.0 & 54.5 & 7.8 & 0.65 & 23.5 \\
Nematic & 59.0 & 3.1 & 52.2 & 7.8 & 0.56 & 18.7 \\
Licorice extract & 66.6 & 2.0 & 56.5 & 7.2 & 0.61 & 20.2 \\
Rugby & 63.0 & 2.7 & 53.0 & 7.9 & 0.70 & 26.7 \\
Control & 45.7 & 1.8 & 45.7 & 6.9 & 0.49 & 22.8 \\
L.S.D. 5\% & 25.16 & 0.48 & 8.08 & 0.71 & 0.14 & 11.2 \\
\hline
\end{tabular}


Table 4: Effect of treatment on wheat infection with A. tritici.

\begin{tabular}{lcc} 
Attributes Treatment & Infection \% & No. of galls spike $\mathbf{~}^{-1}$ \\
Biocont-T & 77.78 & 1.36 \\
T-113 & 80.55 & 3.37 \\
Nematic & 82.89 & 1.93 \\
Licorice extract & 89.22 & 4.80 \\
Rugby & 45.0 & 0.93 \\
Control & 100.00 & 5.66 \\
L.S.D. 5\% & 28.11 & 0.83 \\
\hline
\end{tabular}

reduce nematode population. Under this context, the use of plant extracts with nematocidals can prove to be an effective, safer, and cheaper control measure [27].

\section{CONCLUSION}

Ear-cockle disease causes great loss of wheat crop. The present study was carried out to evaluate the interactive effect of Trichoderma spp. and plant extracts to be used as alternative substances to control the nematode. It was revealed that biopesticide Biocont-T has proved to be effective in suppressing the $\mathrm{J}_{2}$ of $A$. tritici with a smaller number of galls per spike. This study will be helpful for studying new bioagents and plant extracts as alternatives to expensive and harmful chemical nematicides against nematodes in a long-term control program in a wheat plant.

\section{ACKNOWLEDGMENT}

The authors would like to thank the staff of the Seed Inspection and Certification Office and Chief of Mesopotamia Seed Company in Iraq for technical support by providing galls. Also, the authors extend their sincere appreciation to Mrs. Shafaa Ali in the College of Agriculture, University of Wasit, for her valuable assistance during laboratory experiments.

\section{AUTHOR CONTRIBUTIONS}

All authors made substantial contributions to conception and design, acquisition of data, or analysis and interpretation of data; took part in drafting the article or revising it critically for important intellectual content; agreed to submit to the current journal; gave final approval of the version to be published; and agree to be accountable for all aspects of the work. All the authors are eligible to be an author as per the international committee of medical journal editors (ICMJE) requirements/guidelines.

\section{FUNDING}

There is no funding to report.

\section{CONFLICT OF INTEREST}

The authors report no financial or any other conflicts of interest in this work.

\section{ETHICAL APPROVALS}

This study does not involve experiments on animals or human subjects.

\section{PUBLISHER'S NOTE}

This journal remains neutral with regard to jurisdictional claims in published institutional affiliation.

\section{REFERENCES}

1. USDA Foreign Agricultural Service. Grain and feed annual, Iraqi grain production revives in the rain. Ministerio de Agricultura y Ganadería, FAS Cairo, 2019. GAIN Report No: IQ 19001.

2. Dababat AA, Muminjanov H, Smiley R. Nematodes of small grain cereals current status and research. In Fifth International Cereal Nematode Initiative Workshop, 12-15 September 2015, Ankara, Turkey. Food and Agriculture Organization of the United Nations, Ankara, Turkey, 2015.

3. Tiwari SP, Khare MN. Ear-cockle: an important seed-borne disease of wheat. In: KG Mukherji, BP Chamola, AK Sharma (eds.). Glimpses in botany, AK APH Publishing Corporation, New Delhi, India, pp 349-61, 2000.

4. Rao YR. A preliminary list of insect pest of Iraq. Times Press, Bombay, 1921.

5. Othman A. Word of nematodes problem-solution. House of Arabia Press, Cairo, Egypt, p 600, 2008.

6. AL-Beldawi A, Estephan Z, Alwan A, Shali R. Studies on wheat gall nematode in Iraq. Yearbook of Plant Protect. Res., Baghdad, 1977;1:268-83.

7. Al-Baldawi A, Estephan Z, Alwan A, Intwan B, Ismaiel A. Sensitive variety of wheat against seed gall nematode and effect of inoculums levels and date on infection. Iraq Agric Res Water Resour 1985;4:20120 .

8. Stephan Z, Antooan B. Biotypes of earcockle nematode $A$. tritici in Iraq. Curr Nematol 1990;1:85-8.

9. Ami S, Mohammad H, Younis S. Study on ear-cockle disease in some regions of Nineveh province-North of Iraq. Iraqi J Agric Sci 2004;5:95-100.

10. Mustafa S. Study on wheat and barley ear-cockle disease caused nematode $A$. tritici in Erbil province. M.Sc. thesis, College of Agriculture, University of Salahuddin-Erbil, Erbil, Iraq, 2009.

11. Amin A, Abd El-Wanis M. Protecting cucumber against rootkknot nematode, Meloidogyne Incognita using grafting onto resistant cucurbit rootstocks and interplanted Tagetes spp. as an alternatives to Cadusafos nematicide under protected plastic house conditions. Middle East J Agric Res 2014;3(2):167-75.

12. Al-Zemety M, Al-Nather I, Ashoor M. Safety application of pesticides. Arabic Plant Protection Society. Waeel Press, Amman, Jordan, 2011.

13. Al-Malahh N, Muhammed N, Abdul Rassol A. Bio-effect of some pesticide on seed gall nematodes. Kofa J Agric Sci 2012;2(4).

14. Al-Hakeem A. Biological study of Tylenchulus semipenetrans Cobb and some of its control methods. Ph.D. thesis, University of Mosul, College of Agriculture and Forestry, Mosul, Iraq, 2009.

15. Taher IE. Pathology, biology and control of wheat seed gall nematode A. tritici. M.sc thesis, College of Agriculture, University of Duhok, Dahuk, Iraq, 2012.

16. Al-Abdi J. Using some plant extract in control of root-knot nematode Meloidogyne javanica on tomato plant. M.Sc. thesis, College of Agriculture, University of Baghdad, Baghdad, Iraq, p 163, 1985.

17. Ami SN. Integrated pest management of root knot nematode Meloidogyne javanicaon tomato plant. Ph.D. thesis, University of Mosul, College of Agriculture and Forestry, Mosul, Iraq, 1998.

18. Al-Rawei K, Khalaf Allah A. Design and analysis of agriculture experiments. Ministry of higher education and scientific research. House of Book Press University of Baghdad, Baghdad, Iraq, 488 p, 1980.

19. El-Hasan A, Walker F, Buchenauer H. T. harzianum and its metabolite 6-pentyl-alpha-pyrone suppresses fusaric acid produced by Fusarium moniliforme. J Phytopathol 2007;156,79-87. 
20. Pandey A, Namrata D, Bhavesh K, Rinu K, Pankaj T. Phosphate solubilization by Penicillium spp. isolated from soil samples of Indian Himalayan region. World J Microbiol Biotechnol 2008;24:97-102.

21. Khan MR, Altaf S, Mohidin FA, Khan U, Anwer A. Biological control of plant nematodes with phosphate solubilizing microorganisms. In: Khan MS, Zaidi A (eds.). New York phosphate solubilizing microbes for crop improvement, Nova Science Publisher Inc, Hauppauge, NY, pp 395-426, 2009.

22. Barroso C, Pereira G, Nahas E. Solubilization of $\mathrm{CAHPO}_{4}$ and $\mathrm{ALPO}_{4}$ by Aspergillusniger in culture media with different carbon and nitrogen sources. Braz J Microbiol 2006;37:434-8.

23. Ozberk I, Yolcu S, Yucel A, Koten M, Nicol JM. The impact of seed gall nematode on grain yield, quality and marketing prices on durum wheat in Anatolia, Turkey. Afr J Agric Res 2011;6(6):3891-6.

24. Mohamedov a M, Piperkova N. Seed gall nematode A. triticiin BULGARIA: nematode impact on wheat growth and grain yield. Agro Life Sci J 2013;2(2):15-9.

25. Musa T, Al-hadethy A, Naseer K. study some components of Glyeyrrhiza glabrapowder. J Agric Sci 1999;4(4):20-24.
26. Al-Jawary A. Effect of spray of different elements on growth and yield of Capsicum annum L. M.Sc thesis, College of Agriculture, University of Baghdad, Baghdad, Iraq, 2002.

27. Ahmad M, Mukhtar T, Ahmad R. Some studies on the control of citrus nematode Tylenchulus semipenetrans by leaf extracts of three plants and their effects on plant growth variables. Asian J Plant Sci 2004;3(5):544-8.

\section{How to cite this article:}

Al-Taie AHF, Al-Zubaidi NK. Interaction efficiency of Trichoderma spp. and some plant extracts against ear-cockle disease. J Appl Biol Biotech 2022;10(02):102-107. 